\title{
Wealth of the Oceans
}

\author{
Kaufui V. Wong*
}

Mechanical and Aerospace Engineering Department, University of Miami, Coral Gables, FL, USA

\begin{abstract}
Owing to the increasing population, the disparity of natural resources distribution and the variation of climate around the world, there are energy-water-food nexus problems in some countries in the world. It is the objective of the current work to point to the wealth of the oceans as a resource to find all three components. Aquaculture for deep water should also be investigated, and coastal aquaculture expanded. Wind and water technologies for generating electricity or other forms of transportable/storable forms of energy should be researched and developed to a much greater extent. The cost of desalination for potable water should be driven down so that many more countries could afford it. Other pressing reasons for looking to use the oceans more are discussed in this review.
\end{abstract}

Keywords: Food, energy, resources, seas, water.

\section{INTRODUCTION}

"If you look at the increasing world population, we essentially have to double [meat] production by 2050," said Murray, professor at the University of California, Davis [1]. "And we have to do that with less land, less water, and in an environmentally sustainable manner." Murray suggested using genetic engineering of animals, which started about 30 years ago, but none of the genetically modified (GM) animals have been approved by the United States Food and Drug Administration (USFDA). It is the suggestion of the current work to turn to the wealth of the oceans for solutions.

We can look to the seas and oceans for energy, water and food. The resources here will help in solving the problems brought on by the energy-water-food nexus. Energy from water can come both from the potential, kinetic and thermal energies of water, and the magma of the Earth through geothermal energy. Solar energy collection is available without hindrance from forests or buildings.

It is a primeval call. Living organisms could have started near hydrothermal vents in the sea. As sea water level rises, we humans should also return to the sea for answers and solutions. We can respond by adapting and using the bounty provided by the oceans to survive and flourish. After all, our blood density is still pretty close to that of the sea water.

\section{CURRENT STATUS}

About ninety five percent of the oceans have not been explored yet [2]. We need to look at our whole planet, including the deep oceans, to help us support the booming human population.

*Address correspondence to this author at the Mechanical and Aerospace Engineering Department, University of Miami, Coral Gables, FL, USA;

E-mail: kwong@miami.edu
Oil and gas industry is already exploiting resources offshore, many of them in deep water. The ocean floor needs to be mapped in great detail. Machinery and equipment that operate under high pressures should be researched and developed [3].

The fat of sea mammals like whales and dolphins, are very good sources of vitamins A,D and E. The people of Faroe Islands have been hunting and eating cetacean species for years. The species from the order Cetacea include the bottlenose dolphin, white-beaked dolphin, Atlantic whitesided dolphin and harbor porpoise [4].

Whale meat has been consumed in Japan since 12,000 B.C [5]. Modern factory ships were used since the 1930s by the Japanese. They continue to consume whale meat. If proper count is kept of the number of whales surviving and monitoring is undertaken so that the numbers are not being depleted, culling the whale population for food in a sustainable manner should be a consideration.

Desalination of the salty water pumped from the seas has been utilized in countries which can afford them. Innovation is ongoing to try to bring down the costs, including operational costs, of these desalination facilities.

\section{LITERATURE SURVEY}

Bathymetry is the measurement of the ocean depths. Recent works include [6-10]. Courtney and Shaw used multibeam bathymetry and back-scatter imaging to map the Canadian continental shelf [6]. A new grid for Arctic bathymetry was presented in [7]. The objective was to get a better map of the ocean floor north of latitude $64 \mathrm{~N}$. Kostylev et al. [8] reported their work with multibeam bathymetry. In [9], highresolution airborne imagery was used in the Bahamas Banks. Global bathymetry is discussed in [10].

In 2001, Naylor et al. [11] predicted that there would be a five times increase in domestic aquaculture products by 
2025. The researchers [11] reported that the global aquaculture had increased output by more than twice in value and volume for the decade prior to 2001, and supplied one-third of the seafood worldwide. In [12], Liu and Cordes discussed the use of Deoxyribonucleic acid marker technologies in aquaculture genetics. The researchers in [13] deplored the loss of stock in mollusc production owing to disease. None of these academic articles on aquaculture refer to aquaculture in deeper waters. The work in [11] refers to inland and coastal waters.

The place of deep water science and engineering is important if mankind is to use the deep waters more. Webster [14] wrote a review about the part played by the processes in hydrology with respect to the interactions between the oceans and the atmosphere. Chahine [15] wrote about the hydrological cycle and its impact on climate. Pierrehumbert [16] studied the hydrologic cycle in deep-time climate problems. The researchers in [17] published about sea-level and deep water temperature changes. In [18], the scientists studied the variations in the circulation of the depths of the east Atlantic Ocean in the previous thirty thousand years. The researchers in [19] studied the total hydrology (both surface and deep water) of the North Atlantic Ocean for the past one hundred and fifty thousand years.

Ocean Thermal Energy Conversion (OTEC) has been developed, but has yet to find widespread adoption. Finney [20] concluded that OTEC could be viable in tropical areas where the shipping costs of fuels and goods are high. The researchers in [21] studied an OTEC plant boosted by solar energy. In [22], they published about an OTEC- Offshore Solar Pond design.

\section{RESEARCH AND DEVELOPMENT}

A complete and detailed map of the ocean floors would be needed to properly use the resources there. In addition, the principal life forms living at the various levels need to be noted and recorded. It is expected that greater detail needs to be found for the deep trenches around the world, e.g. Mariana Trench, Java Trench. The Mariana Trench in the western Pacific, is the deepest trench in the world. It has a depth of $10.911 \mathrm{~km}(10,911 \pm 40 \mathrm{~m})$ or $6.831 \mathrm{mi}(36,069 \pm$ $131 \mathrm{ft})[23]$.

Not only the trenches, the ridges of the oceans can be rather deep also. The Mid-Indian Ridge has an average depth of $10.0 \mathrm{~km}$ or 6.2 miles. The Mid-Atlantic ridge has a deep rift valley in conformity to its crest. The canyon is about 1 to $3 \mathrm{~km}$ deep. For instance, greater details need to be found if this is an area to be investigated for deep water aquaculture.

With the objective of supplying food to the teeming billions of the world, a master plan for the oceans should be discussed and agreed upon. The wild creatures of the sea should be all identified and recorded. Their migratory routes should be known. Animal and plant life suitable for food should be considered for aquaculture. Areas for these aquaculture projects should be designated, monitored and verified to be environmentally friendly and sustainable before very large scale aquaculture is allowed.

Possible food species should be explored and recognized. New food sources are required, especially protein sources to supplement meat production on land for the teeming billions.
Research and development should be done to make unusual sea foods more palatable, harmless and nutritious.

In the present day, hydrothermal vents are natural occurrences underwater which teem with life that can withstand the toxic chemicals present. The field of human knowledge would benefit by studying living organisms there. For example, one objective could be to learn what features and/or genes they have that allow them to survive under those harsh conditions.

An innovative method has been proposed by the authors in [24] for sail boats to produce hydrogen. This is energy from the wind, deployed in the open seas where the winds are stronger than on land. The researchers in [25] proposed exploiting the West Wind Drift to generate electric power. The West Wind Drift refers to the westerly winds blowing in the region between the continent of Antarctica and the other southern continents. Beneath them, the water currents are also moving in the same direction. These incessant movements of the water and the wind would be an excellent source of energy to produce electric power if the engineering problems are solved, and/or existing technologies made less expensive and practical. Hydraulic turbines could be placed in the powerful currents, closer rather than further from land, and the electricity generated can be transmitted to populated areas via cables.

One recent publication about using the winds over the oceans as a source of energy is [26]. In [26], the proposal is to generate electric power for the whole world. For practical and political reasons, modification of the power energy generation and storage for individual nations would be more acceptable. The hydraulic turbine is used to facilitate the success of the system in [26]. It would seem that under ideal conditions, the hydraulic turbines would generate power well by the ship driven by the wind, but only prototyping and tests would indicate whether the parawing would pull the ship (and hence the hydraulic turbines) off the water often enough to make the system very inefficient. The innovative article about land-sail vehicle to generate electricity [27] may be modified for use over the sea. The encouraging message in [27] is that there could be a significant jump in windgenerated electric power if scientists and engineers looked outside Betz's law.

Desalination plants should be made more efficient, and less expensive to operate. The researchers in [28] wrote about the advances in desalination technologies, and the costs of operation. They came up with some suggestions for how the price of desalination might go down. Karagiannis and Soldatos [29] performed a cost literature review. It seems that the significant factors in desalination costs are the desalting method, the level of salinity in the feedwater, the capacity of the desalination plant and the energy supply. In [28]. solar energy costs the most, but with the least environmental impact. However, solar energy costs have come down owing to affordable organic solar collectors, so the costs of desalination can also be driven downwards.

\section{DISCUSSION AND CONCLUSION}

Aquaculture should be encouraged and increased to meet the rising food demand in the world. Deep water aquaculture should be explored and initiated. The whale is a denizen of 
the deep, however temporary, that seems to have satisfied the palate of the Japanese people.

Wind and water power generation technologies should be increased and implemented. Solar energy collection in the open oceans should be considered. Hydraulic turbines seem to be rather promising, and work should continue.

Desalting the sea water should definitely be a priority to make present technologies more affordable to poorer nations. Solar energy should be used as much as possible with respect to the desalination processes.

People have lived successfully for short periods underwater, for example, an underwater hotel in the Florida Keys, United States of America. The sailors in submarines do regular duty underwater for extended periods of time. Underwater built environments have been used to simulate outer space environments with respect to space exploration. It should be a consideration to research human beings living 'permanently' in communities under deep water conditions.

In the discussion about climate change and global warming, it is a popular thought that the oceans are the world's heat sink. In other words, the oceans are reservoirs for Nature's heat sequestration. If this is indeed the case, we need to know whether life forms in the depths are being adversely affected by this added thermal load. The onus is on us to know what lives there, and to make sure that climate change is not hurting life forms in the ocean depths. We, humans, are after all, custodians of the world.

It is clear that the problems brought on by the energywater-food nexus would be solved by tapping more into the resources of the oceans. Engineering and science research and development will be needed to help human kind move forward. Nature has given the world for us humans to use, as long as we do not abuse the resources.

\section{CONFLICT OF INTEREST}

The author confirms that this article content has no conflict of interest.

\section{ACKNOWLEDGEMENTS}

Declared none.

\section{REFERENCES}

[1] Akst J. Designer Livestock. The Scientist 2014: 42-45.

[2] NOAA, "The Deep Ocean." [Retrieved 9/2/14]. http://oceantoday.noaa.gov/deepocean/

[3] Wong KV. Need for engineering solutions to problems associated with offshore oil and gas production. ASME J Energy Resour Technol 2014; 136(3): 034702.

[4] Wikipedia. Whaling in the Faroe Islands. [Retrieved 8/29/14]. http://en.wikipedia.org/wiki/Whaling_in_the_Faroe_Islands.

[5] Wikipedia. Whaling in Japan. [Retrieved 8/29/14]. http://en.wikipedia.org/wiki/Whaling_in_Japan.
[6] Courtney RC, Shaw J. Multibeam bathymetry and back-scatter imaging of the Canadian continental shelf. Geosci Can 2000; 27 : $31-42$.

[7] Jakobsson M, Cherkis N, Woodward J, Macnab R, Coakley B New grid of Arctic bathymetry aids scientists and mapmakers. EOS, Trans Am Geophys Union 2000; 81(9): 89-96.

[8] Kostylev VE, Todd BJ, Fader GB, Courtney RC, Cameron GD, Pickril RA. Benthic habitat mapping on the Scotian Shelf based on multibeam bathymetry, surficial geology and sea floor photographs. Mar Ecol Prog Ser 2001; 219: 121-37.

[9] Dierssen HM, Zimmerman RC, Leathers RA, Downes TV, Davis $\mathrm{CO}$. Ocean color remote sensing of seagrass and bathymetry in the Bahamas Banks by high-resolution airborne imagery. Moss landing marine labs CA 2003.

[10] Becker JJ, Sandwell DT, Smith WHF, et al. Global bathymetry and elevation data at 30 arc seconds resolution: SRTM30 PLUS. Mar Geodesy 2009; 32(4): 355-71

[11] Naylor RL, Williams SL, StrongDR, Aquaculture-a gateway for exotic species: 2001. [Retrieved 9/01/14]. http://faculty.wwu.edu/ shulld/ESCI\%20432/Sci2001-AquInvasives.pdf.

[12] Liu ZJ, Cordes JF. DNA marker technologies and their applications in aquaculture genetics. Aquaculture 2004; 238(1): 1-37.

[13] Kesarcodi-WA, Kaspar H, Lategan MJ, Gibson L. Probiotics in aquaculture: the need, principles and mechanisms of action and screening processes. Aquaculture 2008; 274(1): 1-14.

[14] Webster PJ. The role of hydrological processes in ocean-atmosphere interactions. Rev Geophys 1994; 32(4): 427-76.

[15] Chahine MT. The hydrological cycle and its influence on climate Nature 1992; 359(6394): 373-80.

[16] Pierrehumbert RT. The hydrologic cycle in deep-time climate problems. Nature 2002; 419(6903): 191-8.

[17] Waelbroeck C, Labeyrie L, Michel E, et al. Sea-level and deep water temperature changes derived from benthic foraminifera isotopic records. Q Sci Rev 2002; 21(1): 295-305.

[18] Sarnthein M, Winn K, Jung SJ, et al. Changes in east Atlantic deepwater circulation over the last 30,000 years: Eight time slice reconstructions. Paleoceanography 1994; 9(2): 209-67.

[19] Labeyrie L, Vidal L, Cortijo E, et al. Surface and deep hydrology of the Northern Atlantic Ocean during the past 150,000 years. Philos Trans R Soc London Ser B Biol Sci 1995; 348(1324); 255-264.

[20] Finney K. Ocean thermal energy conversion. Guelph Eng J 2008; 1: 17-23.

[21] Yamada N, Hoshi A, Ikegami Y. Performance simulation of solarboosted ocean thermal energy conversion plant. Renew Energy 2009; 34(7): 1752-58.

[22] Straatman PJ, Van Sark WG. A new hybrid ocean thermal energy conversion-Offshore solar pond (OTEC-OSP) design: a cost optimization approach. Sol Energy 2008; 82(6): 520-7.

[23] Wikipedia. Mariana Trench. [Retrieved 8/31/14]. http://en.wikipedia.org/wiki/Mariana_Trench.

[24] Platzer MF, Sarigul-Klijin N, Young J, Ashraf MA, Lai JCS. Renewable hydrogen production using sailing ships. J Energy Resour Technol 2014; 136: 5.

[25] Wong KV, Hutley T, Salgado E. Offshore wind power and its potential for development in the west wind drift. ASME Int Mech Eng Congr Exp 2010; 5: 1161-9.

[26] Kim J, and Park C. Wind power generation with a parawing on ships, a proposal. Energy 2010; 35: 1425-32.

[27] Wong KV. Land-sail Vehicle to generate electricity. J Energy Resour Technol 2014; 137(1): 3 .

[28] Khawaji AD, Kutubkhanah IK, Wie JM. Advances in seawater desalination technologies. Desalination 2008; 221(1): 47-69.

[29] Karagiannis IC, Soldatos PG. Water desalination cost literature: review and assessment. Desalination 2008; 223(1): 448-56. 